\title{
Gene Expression Analysis of $G \alpha_{13}{ }^{-/-}$Knockout Mouse Embryos Reveals Perturbations in $G \alpha_{13}$ Signaling Related to Angiogenesis and Hypoxia
}

\section{Ji Hwan Park and Sangdun Choi*}

Department of Molecular Science and Technology, Ajou University, Suwon 443-749, Korea

\begin{abstract}
Angiogenesis is regulated by a large number of molecules and complex signaling mechanisms. The $G$ protein $\mathrm{G} \alpha_{13}$ is a part of this signaling mechanism as an endothelial cell movement regulator. Gene expression analysis of $G \alpha_{13}$ knockout mouse embryos was carried out to identify the role of $\mathrm{G} \alpha_{13}$ in angiogenesis signaling during embryonic development. Hypoxia-inducible response factors including those acting as regulators of angiogenesis were over expressed, while genes related to the cell cycle, DNA replication, protein modification and cell-cell dissociation were under expressed. Functional annotation and network analysis indicate that $G a_{13}{ }^{-1}$ embryonic mice were exposed to hypoxic conditions. The present analysis of the time course highlighted the significantly high levels of disorder in the development of the cardiovascular system. The data suggested that hypoxia-inducible factors including those associated with angiogenesis and abnormalities related to endothelial cell division contributed to the developmental failure of $G \alpha_{13}$ knockout mouse embryos.
\end{abstract}

Keywords: angiogenesis, gene expression, $\mathrm{G}$ protein $\mathrm{G} \alpha_{13}$, $\mathrm{G}$ protein signaling, hypoxia

\section{Introduction}

The heterotrimeric $(\alpha \beta \gamma) \mathrm{G}$ proteins (guanine nucleotide binding proteins) are molecular switches that turn on intracellular signaling cascades in response to the activation of GPCR (G protein coupled receptor) by extracellular stimuli (Oldham and Hamm, 2008). These $G$ proteins are classified into four different families ( $\mathrm{G} \alpha_{\mathrm{s}}$, $\mathrm{G} \alpha_{\mathrm{i} / \mathrm{o}}, \mathrm{G} \alpha_{\mathrm{q} / 11}$ and $\mathrm{G} \alpha_{12 / 13}$ ) based on the nature of the

*Corresponding author: E-mail sangdunchoi@ajou.ac.kr Tel +82-31-219-2600, Fax +82-31-219-1615

Received 10 October 2011, Revised 23 November 2011, Accepted 30 November 2011
$\mathrm{G} \alpha$ subunit present in the heterotrimer (Simon et al., 1991). $\mathrm{G} \alpha_{13}$ belongs to the well studied, albeit poorly understood, $\mathrm{G} \alpha_{12}$ family (Riobo and Manning, 2005). Initially, $\mathrm{G} \alpha_{12}$ and $\mathrm{G} \alpha_{13}$ were shown to induce neoplastic transformations in Rat-1 fibroblasts when activated constitutively (Voyno-Yasenetskaya et al., 1994). It was only later that the true function of $G \alpha_{13}$ was determined when it was shown that $\mathrm{G} \alpha_{13}$, but not $\mathrm{G} \alpha_{12}$, was involved in the LPA (lysophosphatidic acid)-induced activation of Rho (Gohla et al., 1998).

Subsequent studies identified p115 RhoGEF (Rho guanine nucleotide exchange factor 1 or also known as ARHGEF1) as the guanine nucleotide exchange factor involved in the $\mathrm{G} \alpha_{13}$-mediated Rho activation (Hart et al., 1998; Kozasa et al., 1998). $\mathrm{G} \alpha_{12} / \mathrm{G} \alpha_{13}$ proteins also activate several RhoGEFs such as PDZ-RhoGEF (Fukuhara et al., 1999), Lbc-RhoGEF (Dutt et al., 2004) and LARG (leukemia-associated RhoGEF; RhoGEF12) (Suzuki et al., 2003). Once activated by these factors, Rho triggers a cascade of cellular signals mediated by Rho-dependent kinase (ROCK) (Riobo and Manning, 2005). G $\alpha_{12}$ and $\mathrm{G} \alpha_{13}$ not only regulate the activity of low molecular weight $G$ proteins of the Rho family, but also the $\mathrm{Na}^{+} / \mathrm{H}^{+}$ exchanger (Dhanasekaran et al., 1994), phospholipase D (PLD) (Plonk et al., 1998) and inducible nitric oxide synthase (iNOS) (Kitamura et al., 1996). Recently, it was shown that $\mathrm{G} \alpha_{12} / \mathrm{G} \alpha_{13}$ basally regulated $\mathrm{p} 53$ by serine phosphorylation via mdm4 and this phosphorylation event was found to be distinct from p53 phosphorylation elicited by genotoxic agents (Kim et al., 2007).

$\mathrm{G} \alpha_{13}$ is necessary for formation of actin stress fibers (Gohla et al., 1999), focal adhesion (Buhl et al., 1995), increasing $\mathrm{Na}^{+} / \mathrm{H}^{+}$exchange (Voyno-Yasenetskaya et al., 1994), aggregation of platelets (Huang et al., 2007), differentiation of embryonic cells (Jho and Malbon, 1997) and apoptosis (Berestetskaya et al., 1998). In the growth factor-induced cell migration, $\mathrm{G} \alpha_{13}$ promotes the receptor tyrosine kinase (RTK) signaling which is independent of GPCR (Shan et al., 2006). G $\alpha_{13}$ and Rac-dependent cell migration is mediated by the formation of lamellipodia (Dhanasekaran, 2006) and the polymerization of actin to the leading edge of the cell (Radhika et al., 2004).

$\mathrm{G} \alpha_{13}$ is also involved in patterning of blood vessels by controlling cell movement, shape and cell-cell/cellmatrix interactions of the endothelial cells (Ruppel et al., 
2005). Endothelial cells of $G \alpha_{13}$ knockout mice lose the ability to form an organized vascular system, resulting in intrauteric death (Offermanns et al., 1997). Moreover, the head mesenchyme of E8.5-E9.5 (embryo stage 8.5-9.5 day) $G a_{13}$ homozygous knockout mouse embryos exhibited enlarged blood vessels in comparison to the small vessels found in the wild-type or heterozygous embryos. This suggested that $\mathrm{G} \alpha_{13}$ activated physiological angiogenesis rather than vasculogenesis (Offermanns et al., 1997).

The development of blood vessels from differentiation of endothelial cells is called vasculogenesis. On the other hand, the subsequent sprouting of new blood vessels from the organized vascular system is referred to as angiogenesis. Angiogenesis is regulated by a number of stimulators and inhibitors in sophisticated ways. Once activated, epithelial cells begin to degrade the extracellular matrix and loosen the cell-cell adhesion. The adhesion molecules can then help in the sprouting of new blood vessels that are subsequently connected to existing vessels and stabilized with remolded tissues (Pandya et al., 2006).

During embryonic development, Vegf (vascular endothelial growth factor) is a key activator of angiogenesis as well as earlier vasculogenesis. The expression of Vegf is modulated by numerous cytokines such as interleukin 1 beta (IL1 $\beta$ ) (Maruyama et al., 1999), CD40 (Tai et al., 2002), tumor necrosis factor alpha (TNF $\alpha$ ) (Nabors et al., 2003), transforming growth factor beta (TGF $\beta$ ) (Wang et al., 2004) and growth factors such as fibroblast growth factor 2 (FGF2) (Seghezzi et al., 1998). Hypoxia-initiated angiogenesis also occurs through the Vegf signaling pathway (Shweiki et al., 1992). Angiogenesis is thus important to both physiological and pathological conditions such as embryonic development, cancer cell metastasis, wound healing, etc.

Microarray analysis of whole genome expression of $G \alpha_{13}$ knockout mouse embryos was carried out in order to identify the role of $\mathrm{G} \alpha_{13}$ in signaling networks during mouse embryonic development. Whole genome expression data highlighted significantly increased levels of disorder in the development of the physiological systems. Considering the importance of angiogenesis in embryonic or tumor development, it should be very crucial to understand the link between angiogenesis and $\mathrm{G} \alpha_{13^{-}}$ mediated signaling.

\section{Methods}

\section{Generation of $G_{a_{13}}$ knockout mouse embryos}

The generation of $G a_{13}$ knockout mouse embryos is described elsewhere (Offermanns et al., 1997). Briefly, the first two exons of the $G \alpha_{13}$ clone isolated from a 129/Sv mouse genomic $\lambda$ phage library were replaced with neo gene from the plasmid pMC1neo Poly A (Stratagene, USA). The targeting vector contained a 1.4 kb-upstream sequence as the $5^{\prime}$ arm, with $8 \mathrm{~kb}$ of intron sequence and the second exon as the $3^{\prime}$ arm. Gene targeting was carried out in the mouse embryonic stem (ES) cell line CJ7. Correctly targeted ES cell clones were injected into $\mathrm{C} 57 \mathrm{BL} / 6$ blastocysts and chimeras were bred with C57BL/6 and 129/Sv mice to generate heterozygous animals (Ramírez-Solis et al., 1993). Heterozygous mice were interbred to generate homozygous-deficient (knockout) embryos in $G a_{13}$ or wild-type littermate embryos for the controls. All procedures involving mice were carried out in accordance with the guidelines of the ethical committee of Ajou University.

\section{Genotyping of mutant mouse strains}

Total RNA was purified from the embryo or from the yolk sac and used for RT-PCR analysis with $G a_{15}$ specific primers. Oligonucleotides used for PCR reaction were 5'-AGC AGC GCA AGT CCA AGG AGA TCG-3' and 5'-AGG AAC ACT CGA GTC TCC ACC ATC C-3'. The genotypically confirmed knockout embryo sample was directly compared to the wild-type littermate embryo sample.

\section{DNA microarray}

Total RNA was extracted from knockout and wild-type littermate embryos using the Trizol method (Invitrogen, USA) and DNA microarray analysis was performed using the Affymetrix in situ synthesized GeneChip as described on the website of the Alliance for Cellular Signaling (AfCS: http://www.signaling-gateway.org/data/cgi-bin/ ProtocolFile.cgi/afcs_PP00000174.pdf?pid=PP00000174). Briefly, total RNA was prepared from embryos with the use of Trizol (Life Technologies, USA). After the Trizol extraction, cleanup was carried out with a Qiagen RNeasy Mini Kit (Qiagen, USA). Reverse transcription was performed to generate double-stranded cDNAs with the use of SuperScript polymerase (Life Technologies) and an oligo-(dT)24 primer with a T7 RNA polymerase promoter (Genset, USA). An RNA Transcript Labeling Kit (Enzo Diagnostics, USA) was used for the production of hybridizable biotin-labeled RNA targets by in vitro transcription from T7 RNA polymerase promoters. The cDNA prepared from total RNA was used as a template in the presence of a mixture of unlabeled ATP, CTP, GTP, and UTP and biotinylated CTP and UTP. The biotinylated cRNA was hybridized for $16 \mathrm{~h}$ at $40^{\circ} \mathrm{C}$ to a set of oligonucleotide arrays in the GeneChip Fluidics 
Station 400 (Affymetrix, USA). After hybridization, the GeneChip array underwent a series of stringency washes and was stained with streptavidin-conjugated phy- coerythrin. Arrays were scanned with a Hewlett-Packard Scanner.

Table 1. Functions of the genes in cluster $A$ of Fig. 1B

\begin{tabular}{|c|c|c|c|c|c|c|c|}
\hline Symbol & Gene name & Function & 9.5 day & 9.75 day & 10 day & 10.5 day & References \\
\hline$A d m$ & Adrenomedullin & Migration, proliferation & 3.2 & 4.2 & 5.3 & 3.5 & Cormier-Regard et al., 1998 \\
\hline Anxa2 & Annexin A2 & Growth & 0.5 & 1.1 & 1.1 & 1.5 & Hoang et al., 2001 \\
\hline Bh/hb2 & $\begin{array}{l}\text { Basic helix-loop-helix domain } \\
\text { containing, class } B, 2\end{array}$ & Differentiation & 0.9 & 4.5 & 3.4 & 3.1 & Bosco et al., 2006 \\
\hline Bnip3 & $\begin{array}{l}\text { BCL2/adenovirus E1B } 19 \mathrm{kDa} \text { interacting } \\
\text { protein } 3\end{array}$ & Apoptosis & 1.5 & 1.4 & 1.8 & 1.8 & Bosco et al., 2006 \\
\hline Cong2 & Cyclin G2 & Cycle progression & 1.3 & 1.4 & 2.1 & 1.6 & Bosco et al., 2006 \\
\hline Clcn3 & Chloride channel 3 & Ion channel & 0.6 & 1.1 & 1.7 & 2.3 & \\
\hline Ddit4 & DNA-damage-inducible transcript 4 & Differentiation & 2.9 & 3.5 & 3.7 & 3.3 & Schwarzer et al., 2005 \\
\hline Eg/n1 & EGL nine homolog 1 & Cell death & 1.3 & 1.6 & 1.6 & 1.4 & Bosco et al., 2006 \\
\hline Eif2s3y & $\begin{array}{l}\text { Eukaryotic translation initiation factor } 2 \text {, } \\
\text { subunit 3, Y-linked }\end{array}$ & Translation & & -3.5 & & 4.1 & \\
\hline Ero1l & ERO0-like (S. cerevisiae) & Protein modification & 1.2 & 1.8 & 2.4 & 2.1 & Bosco et al., 2006 \\
\hline$F 2$ & Coagulation factor II (thrombin) & $\begin{array}{l}\text { Cell adhesion, } \\
\text { proliferation }\end{array}$ & & & & 4.4 & \\
\hline Foxo3a & Forkhead box o3a & Inhibit migration & 0.9 & 1.3 & 1.4 & 1.2 & \\
\hline Gdap10 & $\begin{array}{l}\text { Ganglioside-induced } \\
\text { differentiation-associated-protein } 10\end{array}$ & Differentiation & 1.4 & 1.1 & 1.7 & 1.2 & \\
\hline Glycam 1 & $\begin{array}{l}\text { Glycosylation dependent cell adhesion } \\
\text { molecule } 1\end{array}$ & Cell adhesion & 0.8 & 1.7 & 1.6 & 1.2 & \\
\hline Gpi1 & Glucose phosphate isomerase 1 & Glycolysis & 0.7 & 1.2 & 1.8 & 1.1 & Bosco et al., 2006 \\
\hline Hspa1a & Heat shock protein $1 \mathrm{~A}$ & Protein modification & 1.8 & 1.7 & 1.7 & 2.3 & Olbryt et al., 2006 \\
\hline ler3 & Immediate early response 3 & Apoptosis & & 2.4 & 3 & 1.8 & \\
\hline lgfbp3 & $\begin{array}{l}\text { Insulin-like growth factor binding } \\
\text { protein } 3\end{array}$ & Apoptosis, growth & 1.3 & 3.1 & 1.6 & 2.4 & Tazuke et al., 1998 \\
\hline$K d r$ & Kinase insert domain protein receptor & Vegf signaling & 1 & 1 & 1 & 1.1 & Bosco et al., 2006 \\
\hline Ndrg1 & $\mathrm{N}$-myc downstream regulated gene 1 & Differentiation & 0.9 & 2.2 & 2.7 & 2.2 & Chen et al., 2006 \\
\hline P4ha1 & $\begin{array}{l}\text { Procollagen-proline, 2-oxoglutarate } \\
\text { 4-dioxygenase, } \alpha 1 \text { polypeptide }\end{array}$ & Collagen synthesis & 0.9 & 1.7 & 1.7 & 1.5 & Bosco et al., 2006 \\
\hline P4ha2 & $\begin{array}{l}\text { Procollagen-proline, 2-oxoglutarate } \\
\text { 4-dioxygenase, } \alpha 1 \text { polypeptide }\end{array}$ & Collagen synthesis & 0.6 & 1.4 & 1.4 & 2 & Bosco et al., 2006 \\
\hline Pbef1 & Pre-B-cell colony-enhancing factor 1 & Differentiation & 0.9 & 1.2 & 1.5 & 1.4 & Wang et al., 2005 \\
\hline Pfkp & Phosphofructokinase, platelet & Glycolysis & 1.4 & 3.8 & 2.5 & 4.1 & Bosco et al., 2006 \\
\hline Pgm2 & Phosphoglucomutase 2 & Glycolysis & 0.9 & 1.9 & 1.7 & 1.7 & Manjunath et al., 1998 \\
\hline Pkp2 & Plakophilin 2 & Cell adhesion & 0.5 & 1.3 & 1 & 1.2 & Olbryt et al., 2006 \\
\hline Rnf19 & Ring finger protein 19 & $\begin{array}{l}\text { Cytoskeleton } \\
\text { biogenesis }\end{array}$ & 0.9 & 1.1 & 1.5 & 1.2 & \\
\hline Rora & RAR-related orphan receptor alpha & $\begin{array}{l}\text { cGMP metabolic } \\
\text { process }\end{array}$ & & 2.7 & 1.1 & 1.7 & Chauvet et al., 2004 \\
\hline Siat4a & $\begin{array}{l}\text { ST3 beta-galactoside } \\
\text { alpha-2,3-sialyltransferase } 1\end{array}$ & $\begin{array}{l}\text { Protein amino acid } \\
\text { glycosylation }\end{array}$ & 1 & 1.3 & 1.4 & 1.4 & Koike et al., 2004 \\
\hline Slc2a1 & $\begin{array}{l}\text { Solute carrier family } 2 \text { (facilitated } \\
\text { glucose transporter), member } 1\end{array}$ & Glucose transport & 0.9 & 1.8 & 1.1 & 1.4 & Bosco et al., 2006 \\
\hline Slc2a3 & $\begin{array}{l}\text { Solute carrier family } 2 \text { (facilitated } \\
\text { glucose transporter), member } 3\end{array}$ & Glucose transport & 1.4 & 2.1 & 1.7 & 1.9 & Bosco et al., 2006 \\
\hline Stc2 & Stanniocalcin 2 & $\begin{array}{l}\text { Calcium and } \\
\text { phosphate transport }\end{array}$ & 0.9 & 1 & 1.7 & 1.7 & Ito et al., 2004 \\
\hline Tmem45a & Transmembrane protein $45 a$ & Integral to membrane & 3.7 & & 1.3 & 3.6 & Martin-Rendon et al., 2007 \\
\hline Upp1 & Uridine phosphorylase 1 & Nucleoside metabolic & 3.7 & 3.1 & 3.3 & 2.6 & Abramovitch et al., 2004 \\
\hline Vegf & Vascular endothelial growth factor & Vegf signaling & 1.7 & 2.1 & 2.2 & 2.1 & Bosco et al., 2006 \\
\hline
\end{tabular}

Hypoxia-induced genes are indicated in bold with the corresponding references. Folds are shown in $\log _{2} \operatorname{ratio}_{\text {. }}$ 


\section{Data analysis}

The GeneChip was scanned and information was extracted using the GeneChip Analysis Suite 5.0 (Affymetrix). The output $\log _{2}$ ratio represents the fold difference between the knockout and control samples. The GeneChip Analysis program gives a present/absent (P/A) call for each spot on the array based on a predetermined signal-to-noise ratio, along with a not changed/increase/marginal increase/decrease/marginal decrease (NC/ $\mathrm{I} / \mathrm{MI} / \mathrm{D} / \mathrm{MD}$ ) call for the comparison. The genes that had an NC/MI/MD call were filtered out. MeV program (MultiExperiment Viewer: http://www.tm4.org/mev.html) was used for clustering and Ingenuity Pathway Analysis (http://www.ingenuity.com) for functional analysis. All relevant microarray data have been deposited in MIAME (Minimum Information About a Microarray Experiment) compliant format in the public repository, ArrayExpress, under accession number E-MTAB-614.

\section{Functional annotation and network analysis}

For functional enrichment analysis, we used the Cytoscape plugin, BiNGO version 2.44. We selected GO Biological Process ontology file to annotate the GO term and filtered out only significant $G O$ terms ( $p$-value $<$ 0.0001 ) according to Hypergeometric test in BiNGO. We generated the hypothetical network using 23 hypoxia-induced genes listed in Table 1. The first interaction neighbors were obtained from human protein-protein interaction database, BioGrid (http://www.thebiogrid.org). To identify the direct regulation of HIF1 $\alpha$ (hypoxia-inducible factor 1 , alpha subunit) to the hypoxia-induced genes, we performed a literature search which proved the binding of HIF1 $\alpha$ to the promoters of the genes. To reconstruct a compact network, first neighbors of hypoxia-induced genes were removed, excluding the neighbors that interacted with two or more hypoxia-induced genes. Numbers of neighbors including removed neighbors were represented by size of the nodes.

\section{Quantitative real-time PCR (QRT-PCR)}

QRT-PCR was performed on the GeneAmp 5700 Sequence Detection System (Applied Biosystems, USA) by monitoring of the increase in fluorescence caused by the binding of SYBR Green to double-stranded DNA. Total RNA was prepared from frozen mouse retinas with the use of Trizol reagent (Life Technologies). To prepare CDNA templates, $50-100 \mathrm{ng}$ of total RNA was mixed with $5.5 \mathrm{mM} \mathrm{MgCl}_{2}, 0.5 \mathrm{mM}$ each dNTP, $2.5 \mu \mathrm{M}$ random hexamer, 0.4 unit/ $\mu$ I RNase inhibitor, and 1.25 units/ $\mu \mid$ MultiScribe reverse transcriptase from TaqMan
Reverse Transcription Reagents (Applied Biosystems). RT was incubated at $25^{\circ} \mathrm{C}$ for $10 \mathrm{~min}$ and at $48^{\circ} \mathrm{C}$ for $30 \mathrm{~min}$ and inactivated at $95^{\circ} \mathrm{C}$ for $5 \mathrm{~min}$. The PCR primers were designed with primer express software (Applied Biosystems), and their specificity in gene amplification was confirmed by measurement of the size and purity of the PCR product by $4 \%$ NuSieve agarose gel electrophoresis. For a 50- $\mu$ I PCR, $4 \mu \mathrm{l}$ cDNA template was mixed with $300 \mathrm{nM}$ each of forward and reverse primers and $2 \times$ SYBR Green PCR Master Mix (Applied Systems). The reaction was first incubated at $50^{\circ} \mathrm{C}$ for $2 \mathrm{~min}$, then at $95^{\circ} \mathrm{C}$ for $10 \mathrm{~min}$, followed by 40 cycles of $95^{\circ} \mathrm{C}$ for $15 \mathrm{~s}$ and $60^{\circ} \mathrm{C}$ for $1 \mathrm{~min}$. Each gene-specific PCR was performed in triplicate.

\section{Results}

Angiogenesis-related genes were differently regulated in $\mathrm{Ga}_{13^{-1}}$ mouse embryos

Using the Affymetrix GeneChip, gene expressions were measured and significantly regulated genes were selected by statistical filtering ( $\geq 1.5$ fold and $p$-value $\leq$

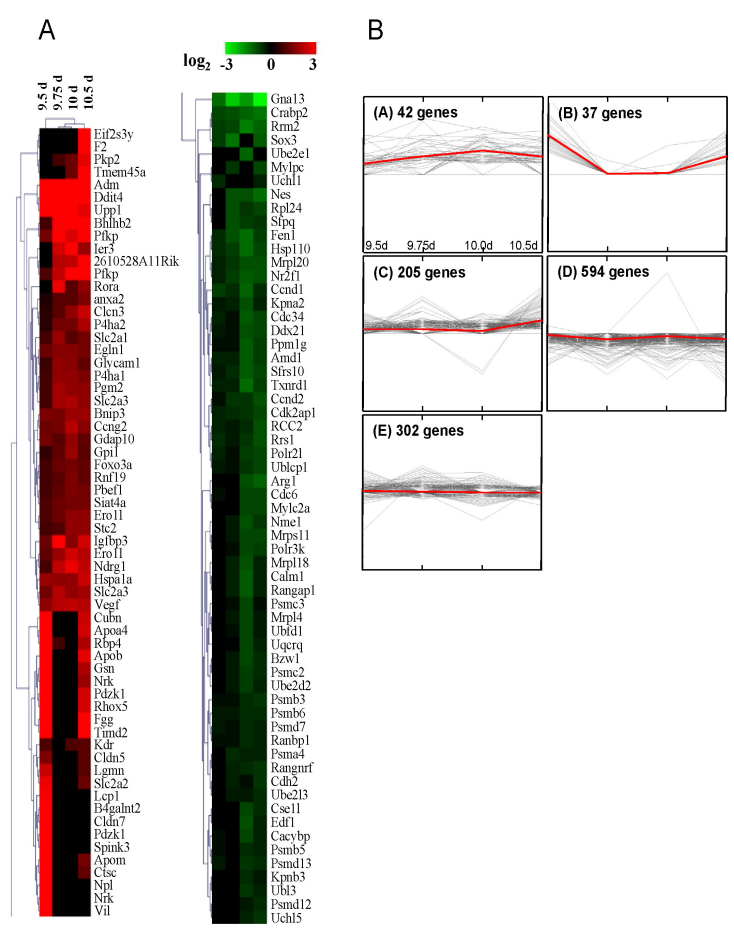

Fig. 1. Clustering analysis. (A) Hierarchical clustering results from MeV. The intensity of color represents the value of upregulation (red) or downregulation (green) in $\log _{2}$ ratio. (B) K-Means clustering results. Altered genes were classified into 5 clusters by the $\mathrm{MeV}$ program. The each line shows changing of each gene over time. 
0.01 in either of four time points). The hierarchical clustering result of significantly regulated genes in the $\mathrm{Ga}_{13}{ }^{-1}$ mouse embryonic development st ages is shown in Fig. $1 \mathrm{~A}$. Using the K-Means method, five expression clusters were obtained (Fig. 1B). Most genes in the cluster A of Fig. 1B were continually and remarkably upregulated from 9.5 day to 10.5 day. Table 1 shows functions of genes in cluster A. Vegf (In our QRT-PCR experiment, Vegf was upregulated by 5.7 fold at 10 day; data not shown) and Kdr (kinase insert domain receptor; Vegf receptor) are key regulators of angiogenesis. Igfbp3 (insulin-like growth factor binding protein 3) (Granata et al., 2007), F2 (coagulation factor 2) (Tsopanoglou and Maragoudakis, 1999) and Adm (adrenomedullin) (Ribatti et al., 2005) induce angiogenesis. Anxa2 (annexin A2) regulates angiogenesis (Ling et al., 2004), and Bnip3 (BCL2/adenovirus E1B interacting protein 3) is related to the reactivity of Vegf (Giatromanolaki et al., 2007). Foxo3a (forkhead box O3a) (Potente et al., 2005) inhibits tube formation. In addition, other molecules related to cell differentiation and cell adhesion could get involved in the formation of blood vessels.

\section{Signal transduction networks}

We used Ingenuity Pathways Analysis (IPA) program to show the interactions between aberrantly expressed molecules as a biological network in $G_{1} a_{13}^{--}$embryos. A subset of genes ( $\geq 0.5$ or $\leq-0.5$ in $\log _{2}$ ratio) regulated at all time points were analyzed by IPA program and as a result we obtained 4 major networks. The top functions of the molecules in networks and their scores are given in Table 2. The network of $9.5 \mathrm{~d} G a_{13} 3^{--}$embryo was related to cell cycle, cancer, and cellular function and maintenance. The names of the molecules in this network which are related to cell cycle include Cond (cyclin D1), Cdkn1C (cyclin-dependent kinase inhibitor 1C), Dcn (decorin), Igf1 (insulin-like growth factor 1), Myb (v-myb myeloblastosis viral oncogene homolog) and Smarca2 (SWI/SNF related, matrix associated, actin dependent regulator of chromatin, subfamily a, member 2). Subsequently, the network of $9.75 \mathrm{~d}$ contained molecules involved in protein synthesis, degradation and cancer, such as Adrm1 (adhesion regulating molecule 1), Fbxo8 (F-box protein 8), Nedd8 (neural precursor cell expressed developmentally down-regulated 8), Psmb3 (proteasome subunit, beta type 3), Psmb5, Psmc2, Psmd14, UbE2D2 (ubiquitin-conjugating enzyme E2D 2) and UbE2E1. On the other hand, 10d network consisted of Adm, Bsg (basigin), CtsL2 (cathepsin L2), Ets2 (v-ets erythroblastosis virus E26 oncogene homolog 2), Igfbp2, Postn (periostin, osteoblast specific factor), Spp1 (secreted phosphoprotein 1) and Vtn (vitronectin) marks for cellular movement. In addition, this particular network consisted of the molecules associated with skeletal/ muscular system development, connective tissue disorders, and dermatological diseases as well. Top-ranked function of the molecules in $10.5 d$ network is involved in cellular movement: Col18 $\alpha 1$ (collagen, type 18, alpha 1), Col1 $\alpha 1$, EfnA1 (ephrin-A1), Meox2 (mesenchyme homeobox 2), NdE1 (nude nuclear distribution gene $\mathrm{E}$ homolog 1), Nrp1 (neuropilin 1), Sema3E (sema domain, immunoglobulin domain, short basic domain secreted, $3 E$ ), Sparc (secreted protein, acidic, cysteine-rich), TGF

Table 2. Scores, top functions and molecules in the networks generated using the IPA program

\begin{tabular}{|c|c|c|c|c|}
\hline Analysis & Score & $\begin{array}{c}\text { Focus } \\
\text { molecules }\end{array}$ & Top functions & Molecules in network \\
\hline $9.5 d$ & 41 & 25 & $\begin{array}{l}\text { Cell Cycle, Cancer, Cellular } \\
\text { Function and Maintenance }\end{array}$ & $\begin{array}{l}\text { ANP32A, ASF1B, Caspase, CBX1, CCND1, CDKN1C, CLK1, CRABP2, CYBA, } \\
\text { Cyclin A, Cyclin E, DCN, DDX17, E2f, FEN1, Hdac, Histone h3, IGF1, ITM2B, } \\
\text { MYB, NADPH oxidase, NCOA6, PCSK5, Rar, Rb, REST, RRM2, Scf, SF3B1, } \\
\text { SFPQ, SFRS1, SFRS3, SMARCA2, VAMP8, ZNF239 }\end{array}$ \\
\hline $9.75 d$ & 44 & 29 & $\begin{array}{l}\text { Protein Degradation, Protein } \\
\text { Synthesis, Cancer }\end{array}$ & $\begin{array}{l}\text { ADRM1, ANKRD1, CACYBP, CDC34 (includes EG:997), COPS3, DDOST, FBXL3, } \\
\text { FBXO8, GPS1 (includes EG:209318), MYBL1, NEDD8, NFkB, PPM1B, } \\
\text { Proteasome, Proteasome PA700/20s, PSMB, PSMB3, PSMB5, PSMB6, PSMC2, } \\
\text { PSMC3, PSMD, PSMD1, PSMD7, PSMD13, PSMD14, SKP1, SRR, TIMM23, } \\
\text { TIMM8A, TXNRD1, UBE2, UBE2D2, UBE2E1, ZNRF1 }\end{array}$ \\
\hline $10 d$ & 42 & 25 & $\begin{array}{l}\text { Cellular Movement, Skeletal } \\
\text { and Muscular System } \\
\text { Development and Function, } \\
\text { Cancer }\end{array}$ & $\begin{array}{l}\text { ACTL6A, ADM, BHLHB2, BSG, Ck2, COPS2, CTSL2, EIF4B, ERK, ETS2, Fibrin, } \\
\text { GATA6, hCG, IGF2R, IGFBP2, IGFBP3, Insulin, Integrin, MAP2K1/2, Mmp, } \\
\text { NAMPT, NDRG2, NR2F1, PCK2, PEA15, PEPCK, POSTN, Raf, SAT1, SCARB1, } \\
\text { SLC2A3, SPP1, STC2, UPP1, VTN }\end{array}$ \\
\hline $10.5 d$ & 44 & 29 & $\begin{array}{l}\text { Cellular Movement, Connective } \\
\text { Tissue Disorders, Dermatological } \\
\text { Diseases and Conditions }\end{array}$ & $\begin{array}{l}\text { Aldehyde dehydrogenase (NAD), ALDH, ALDH1A2, ALDH3A2, ALDH7A1, CDC34 } \\
\text { (includes EG:997), COL18A1, COL1A1, COL1A2, COL3A1, EFNA1, FLI1, MEOX2, } \\
\text { NDE1, NFkB, NFYC, NID2, NRP1, P4HA1, P4HA2, Pdgf Ab, PPIF, Proteasome, } \\
\text { RNF19A, SEMA3E, SLC2A2, SPARC, TACSTD1, TGFBI, TUBG1, TXNRD1, } \\
\text { UBE2, UBE2L3, UBE2S, VEGFC }\end{array}$ \\
\hline
\end{tabular}


$\beta$ I (Transforming growth factor, beta-induced, $68 \mathrm{kDa}$ ) and VegfC. Thus, our approach on network analyses by IPA revealed potential interactive relationships of aberrantly expressed molecules and defects of $\mathrm{Ga}_{13}{ }^{-{ }^{-}}$signaling.

\section{Biological functions enriched with over-ex- pressed genes in $\mathrm{G}_{11}{ }^{-1-}$ mouse embryos}

To identify the functional enrichment of upregulated genes in any of the developmental stages of $\mathrm{Ga}_{13}{ }^{--}$ mouse embryos, we generated the GO term tree using BiNGO plugin of Cytoscape program. We arranged the node representing each function to the hierarchical structure. We then categorized the functions into 12 groups such as response to wounding, metabolic process, regulation of transcription, angiogenesis, macromolecule metabolic process, apoptosis, signaling pathway, lipid metabolic process, transport, cell migration, catabolic process and embryonic development (represented as black boxes in Fig. 2). In particular, we observed that the angiogenesis-related genes were highly expressed in $\mathrm{Ga}_{13}{ }^{-\gamma}$ mouse embryos as indicated by strong enrichment of angiogenesis and their upstream GO terms. We also found that biological functions associated with apoptosis, cell migration and transport that are known to be hypoxia-induced responses were also highly enriched. Based on these results, we hypothesized that $\mathrm{Ga}_{13}{ }^{--}$mouse embryos suffered hypoxic conditions during developmental stage 9.5-10.5 days, where hypoxia-induced responses such as angiogenesis, apoptosis, transport and cell migration were increased.

\section{$G a_{13}$-deletion mimics hypoxia-induced response in $G a_{13}$ knockout embryos}

A hypoxic condition such as newly formatted tissues or cancer cells needs new blood vessels, a source of energy and oxygen supply. In order to ascertain whether hypoxia-related genes were regulated, we looked for those genes that are known to be induced under hypoxic conditions. The hypoxia-related genes are shown in bold and their references are listed in Table 1. Genes associated with angiogenesis, glucose transporters, and ion regulators were among those that were significantly upregulated. For example, in $\mathrm{G} \alpha_{13}{ }^{-/-}$mouse embryos at all the time points tested, the expressions of $A d m$, Bhlhb2 (basic helix-loop-helix domain containing, class B, 2), Bnip3, Cong2 (cyclin G2), Ddit4 (DNA-damage-inducible transcript 4) and $E g / n 1$ (egl nine homolog 1) were higher when compared to normal embryos. Our finding supports that the $\mathrm{Ga}_{13}{ }^{-1-}$ mouse was exposed to hypoxic conditions from 9.5-10.5 days. We next performed network analysis to show the interactive relation-

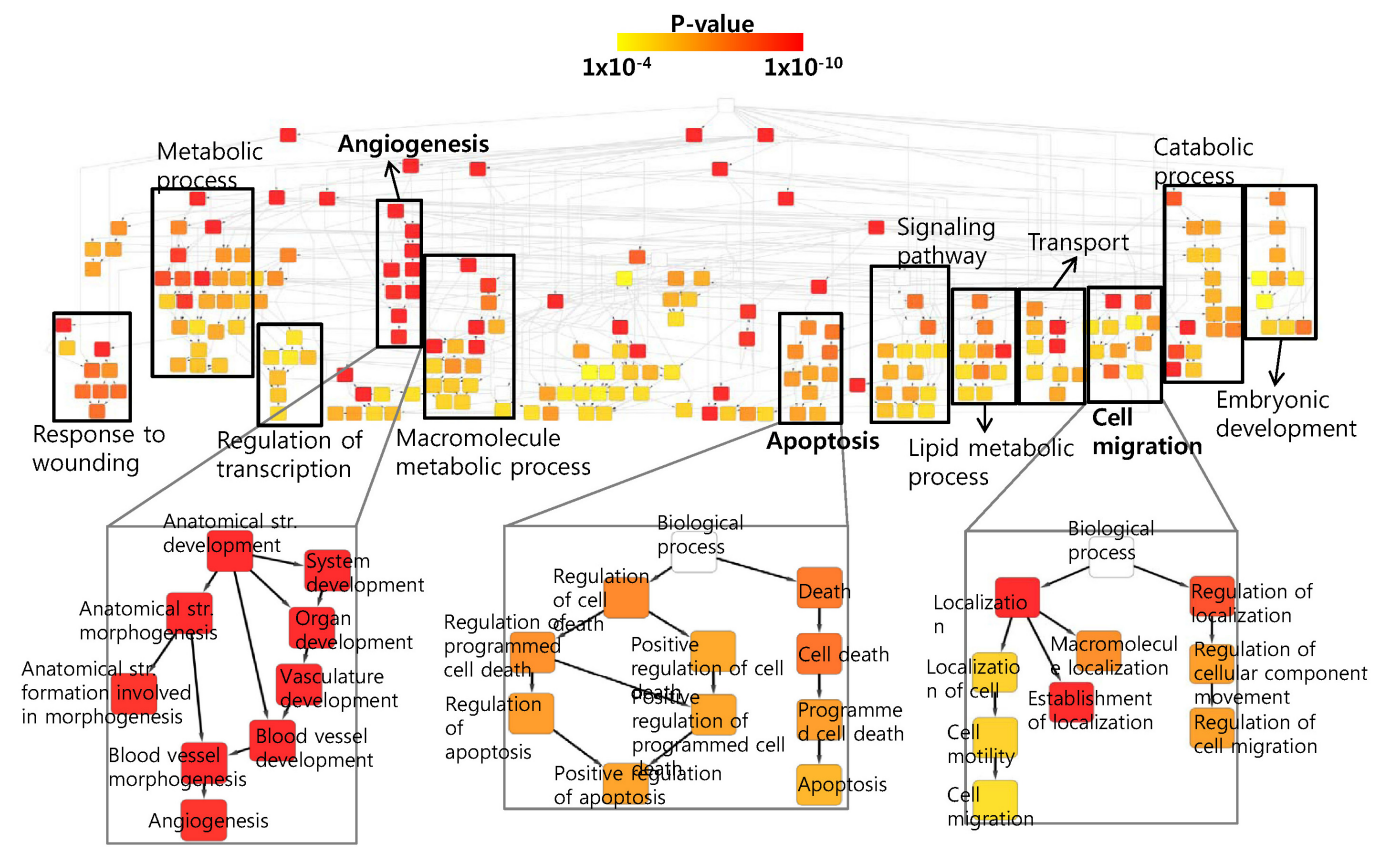

Fig. 2. A GO term tree of over-expressed genes in $\mathrm{Ga}_{13}{ }^{-1}$ mouse embryos generated from BiNGO program. Genes with a log2 ratio of 0.5 or greater in any of developmental days were used to perform functional annotation analysis. The brightness of node colors represents the p-value indicating significance of functional enrichment. The cellular processes were categorized into several groups as indicated by black boxes. 
ships of hypoxia-induced genes listed in Table 1. We investigated the interactions between hypoxia-induced genes and their first neighbors, but displayed only the number of interacting neighbors. The network indicates that most of hypoxia-induced genes over-expressed in $\mathrm{Ga}_{13^{-1}}$ embryonic mouse were mainly transcriptionally regulated by $\mathrm{HIF} 1 \alpha$ directly or indirectly as depicted in Fig. 3 (In our QRT-PCR experiment, Hif1 a was down regulated by 3 fold at 10 day; data not shown). We also observed that several genes in network such as $\mathrm{Hspa1A}$ (heat shock $70 \mathrm{kDa}$ protein $1 \mathrm{~A}$ ), lgfbp3, Vegf, $\mathrm{Kdr}$ and Anxa2 interacted with several neighbor genes, suggesting that these genes play a potent role in $G \alpha_{13}$ knockout-induced hypoxic responses. Moreover, a comparison of our microarray data with another published data (Accession No. E-MEXP-392 in ArrrayExpress database: http://www.ebi.ac.uk/microarray-as/aer/result?queryFor= Experiment\&eAccession=E-MEXP-392) suggested that apart from hypoxia-related genes such as Eg/n1, genes that were responsible for angiogenesis such as Vegf were upregulated in a similar manner as that of embryonic stem cells under hypoxic conditions (Fig. 4), suggesting that in $\mathrm{Ga}_{13}{ }^{--}$embryonic cells, hypoxic condition might exist similarly.

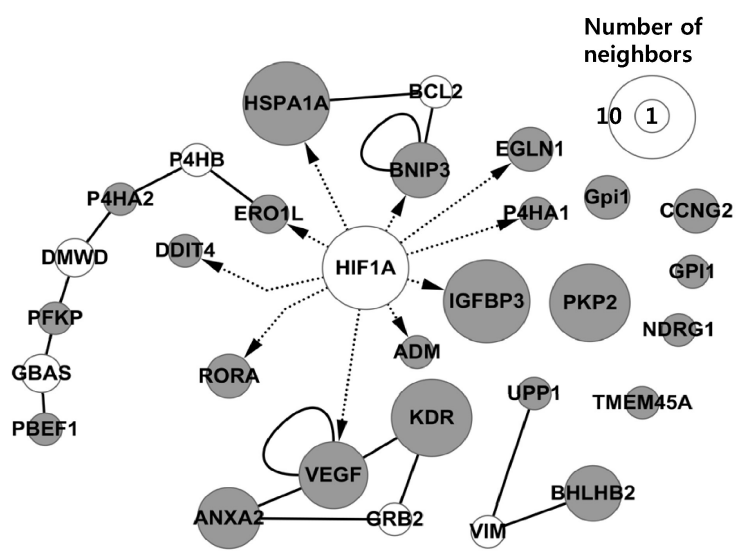

Fig. 3. Graphic view of interactions between hypoxia-induced genes in $\mathrm{Ga}_{13}{ }^{--}$mouse embryos. Continually increased genes which may be affected by hypoxia were used to construct the hypothetical network. First neighbors were omitted on the basis of interaction with only one hypoxia-induced gene and number of neighbors was represented by size of nodes. Grey circles are hypoxia-induced genes and white circles represent their neighbors. Solid lines indicate protein-protein interactions and dashed lines indicate transcriptional regulation.

\section{A number of transcription and translation factors were downregulated in $G \alpha_{13}$ knockout embryos}

Functions of genes that have more than $50 \%$ downregulation in the expression level among filtered genes are summarized in Table 3 . The expression of $G a_{13}$ (also known as Gna13) at 9.5d, 9.75d, 10d and 10.5d $\left(\log _{2}\right.$ ratio values of $-1.3,-1.8,-2.3$ and -2.8 respectively) was confirmed. A number of transcription and translation factors were downregulated. Cell cycle regulators including DNA replication effectors were also downregulated. Some of the important down-regulated genes were Ccnd1, Ccnd2, Ranbp1 (RAN binding protein 1), Ranbp5 (RAN binding protein 5), Cdc6 (cell division cycle 6 homolog), Cdc34 (cell division cycle 34 homolog), Fen1 (flap structure-specific endonuclease 1), Sox3 (SRY-box 3), etc. Ccnd1 and Ccnd2 modulate the matrix metalloproteinase activity and cell motility. Ccnd1 is also involved in the expression of Rac1 (ras-related C3 botulinum toxin substrate 1) that stimulates the dorsal ruffle formation acell motility (Arato-Ohshima and Sawa, 1999; Manes et al., 2003). Rangap1 (Ran GTPase activating protein 1) mediated by Ran (member RAS oncogene family) regulates cell division (Arnaoutov and Dasso, 2003). Ran activity-involved proteins such as Ranbp1, Ranbp5 and Rangnrf (Ran guanine nucleotide release factor) were marginally downregulated. Ppm1g (protein phosphatase 1G, magnesium-dependent, gamma isoform), Rcc2 (regulator of chromosome condensation 2), Kpna2 (karyopherin alpha 2), Cdc6, Cdc34, Fen1 and Rrm2 (ribonucleotide reductase M2 polypeptide) participate in the processing of cell division. Cacybp (calcyclin binding protein) is involved in the calcium-dependent protein degradation process (Filipek, 2006). Ubfd1 (ubiquitin family domain containing 1),

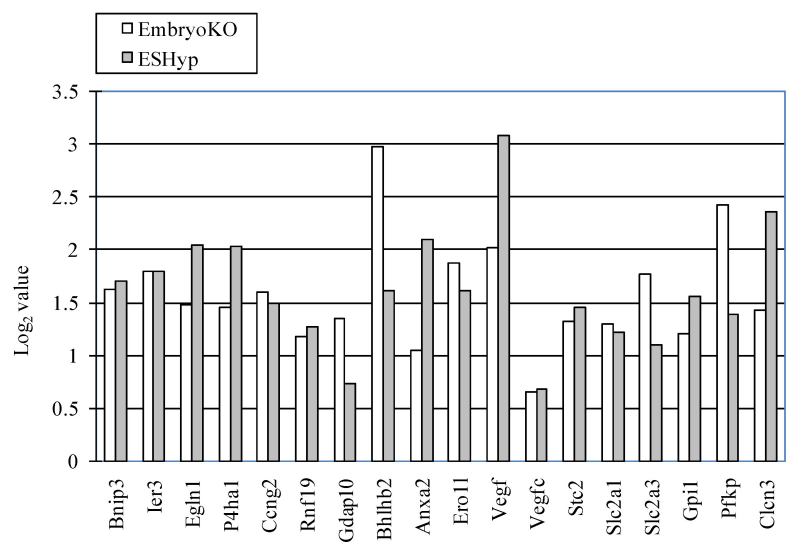

Fig. 4. Comparison of hypoxia or angiogenesis genes upregulated in $\mathrm{Ga}_{13}{ }^{--}$mouse embryos (EmbryoKO) to those regulated in ES cells under hypoxic conditions (ESHyp). 
168 Genomics \& Informatics Vol. 9(4) 161-172, December 2011

Ublcp1 (ubiquitin-like domain containing CTD phosphatase 1) and other ubiquitin-involved proteins that were marginally downregulated play a role in protein modi- fication. Psmc3 (proteasome 26S subunit ATPase 3) promotes the global cellular ubiquitin-tagged protein degradation process (Demartino and Gillette, 2007). Nes

Table 3. Functions of downregulated genes

\begin{tabular}{|c|c|c|c|c|c|c|}
\hline Symbol & Gene name & Function & $\begin{array}{l}9.5 \\
\text { day }\end{array}$ & $\begin{array}{l}9.75 \\
\text { day }\end{array}$ & $\begin{array}{c}10 \\
\text { day }\end{array}$ & $\begin{array}{l}10.5 \\
\text { day }\end{array}$ \\
\hline Amd1 & S-adenosylmethionine decarboxylase 1 & Morphology, metabolism & -0.5 & -1.1 & -0.5 & -0.8 \\
\hline Anp32 & Acidic nuclear phosphoprotein 32 & & -0.9 & -0.6 & -0.6 & -0.6 \\
\hline $\operatorname{Arg} 1$ & Arginase 1 , liver & Arginine metabolism, nervous system development & -0.9 & -1 & -1.1 & -1.2 \\
\hline Bzw1 & Basic leucine zipper and W2 domains 1 & Transcription & & -0.9 & -0.4 & -0.6 \\
\hline Cacybp & Calcyclin binding protein & Ubiquitin & -0.3 & -0.9 & -0.7 & -0.5 \\
\hline Calm1 & Calmodulin 1 & Calcium signaling, migration & & -1.1 & -0.5 & -0.5 \\
\hline Cond1 & Cyclin D1 & Division, migration & -0.8 & -1.2 & -0.6 & -0.6 \\
\hline Ccnd2 & Cyclin D2 & Division, migration & -0.3 & -0.7 & -0.7 & -1 \\
\hline Cdc34 & Cell division cycle 34 homolog (S. cerevisiae) & Ubiquitin, DNA replication & -0.5 & -1.1 & -0.3 & -0.9 \\
\hline Cdc6 & Cell division cycle 6 homolog (S. cerevisiae) & DNA replication & -0.3 & -0.9 & -0.9 & -0.9 \\
\hline Cdh2 & Cadherin 2 (N-cadherin) & Adhesion, vascular morphogenesis & -0.2 & -0.3 & -0.5 & -0.7 \\
\hline Cdk2ap1 & $\begin{array}{l}\text { CDK2 (cyclin-dependent kinase 2)-associated } \\
\text { protein } 1\end{array}$ & Growth suppress & -0.5 & -0.7 & -0.6 & -0.9 \\
\hline Crabp2 & Cellular retinoic acid binding protein II & Transport, differentiation & -0.9 & -1.2 & -1 & -1.4 \\
\hline Cse1/ & Chromosome segregation 1-like (S. cerevisiae) & Transport, proliferation & & -0.9 & -0.8 & -0.6 \\
\hline$D d \times 21$ & $\begin{array}{l}\text { DEAD/H (Asp-Glu-Ala-Asp/His) box polypeptide } \\
21 \text { (RNA helicase II/Gu) }\end{array}$ & Translation & -0.4 & -1 & -0.3 & -0.9 \\
\hline Edf1 & Endothelial differentiation-related factor 1 & Differentiation & & -1 & -0.8 & -0.5 \\
\hline $\begin{array}{r}\text { Elav/1 } \\
\text { (Hur) }\end{array}$ & $\begin{array}{l}\text { ELAV (embryonic lethal, abnormal vision, } \\
\text { Drosophila)-like } 1 \text { (Hu antigen R) }\end{array}$ & Destabilizes mRNAs & -0.4 & -0.7 & -0.4 & -0.6 \\
\hline Fen1 & Flap structure specific endonuclease 1 & DNA replication & -0.6 & -1.3 & -1 & -0.8 \\
\hline Gna13 & Guanine nucleotide binding protein, alpha 13 & G protein signaling & -1.3 & -1.8 & -2.3 & -2.8 \\
\hline Hsp110 & Heat shock protein 110 & Protein modification & -0.6 & -1.3 & -0.8 & -0.9 \\
\hline Kpna2 & Karyopherin (importin) alpha 2 & DNA recombination, transport & -0.4 & -1 & -0.5 & -0.5 \\
\hline Mrp/18 & Mitochondrial ribosomal protein 118 & Translation & & -1 & -0.5 & -0.5 \\
\hline Mrp/20 & Mitochondrial ribosomal protein $\mathrm{I} 20$ & Translation & -0.5 & -1 & -0.7 & -1 \\
\hline Mrp/4 & Mitochondrial ribosomal protein 14 & Translation & & -0.9 & -0.4 & -0.4 \\
\hline Mrps11 & Mitochondrial ribosomal protein s11 & Translation & & -0.9 & -0.4 & -0.9 \\
\hline Mylpc & $\begin{array}{l}\text { Myosin light chain, phosphorylatable, } \\
\text { Cardiac ventricles }\end{array}$ & Adhesion, heart development & & & -0.7 & -0.9 \\
\hline Nes & Nestin & $\begin{array}{l}\text { Intermediate filament protein, central nervous } \\
\text { system development }\end{array}$ & -1 & -1 & -1 & -1.3 \\
\hline Nme1 & $\begin{array}{l}\text { Expressed in non-metastatic cells } 1 \text {, protein } \\
\text { (NM23A) (nucleoside diphosphate kinase) }\end{array}$ & Nucleotide metabolic & & -1 & -0.4 & -0.7 \\
\hline Nr2f1 & Nuclear receptor subfamily 2 , group $F$, member 1 & Neuron migration, forebrain development & -0.5 & -1.1 & -0.8 & -1 \\
\hline Polr2l & Polymerase (RNA) II (DNA directed) polypeptide L & Transcription & -0.5 & -0.8 & -0.3 & -0.9 \\
\hline Polr3k & Polymerase (RNA) III (DNA directed) polypeptide K & Transcription & & -0.9 & -0.3 & -0.8 \\
\hline Ppm1g & $\begin{array}{l}\text { Protein phosphatase } 1 \mathrm{G} \text { (formerly } 2 \mathrm{C} \text { ), } \\
\text { magnesium-dependent, gamma isoform }\end{array}$ & Cell cycle & -0.3 & -1.1 & -0.3 & -0.8 \\
\hline Psmc3 & $\begin{array}{l}\text { Proteasome (prosome, macropain) } 26 \mathrm{~S} \text { subunit, } \\
\text { ATPase } 3\end{array}$ & Protein catabolic & & -0.9 & -0.3 & -0.3 \\
\hline Rangap1 & RAN GTPase activating protein 1 & Ran GTPase, division & & -1.1 & -0.5 & -0.5 \\
\hline RCC2 & Regulator of chromosome condensation 2 & Division & -0.5 & -0.6 & -0.4 & -1 \\
\hline Rp/24 & Ribosomal protein L24 & Translation & & -0.7 & -1 & -0.9 \\
\hline Rrm2 & Ribonucleotide reductase M2 & DNA replication & -0.8 & -1.5 & -0.9 & -1.2 \\
\hline Rrs1 & $\begin{array}{l}\text { RRS1 ribosome biogenesis regulator homolog } \\
\text { (S. cerevisiae) }\end{array}$ & Transcription & -0.6 & -0.7 & -0.4 & -1 \\
\hline Sfpq & $\begin{array}{l}\text { Splicing factor proline/glutamine rich } \\
\text { (polypyrimidine tract binding protein associated) }\end{array}$ & Translation & & -0.8 & -1 & -0.7 \\
\hline
\end{tabular}


Table 3. Continued

\begin{tabular}{|c|c|c|c|c|c|c|}
\hline Symbol & Gene name & Function & $\begin{array}{l}9.5 \\
\text { day }\end{array}$ & $\begin{array}{l}9.75 \\
\text { day }\end{array}$ & $\begin{array}{c}10 \\
\text { day }\end{array}$ & $\begin{array}{l}10.5 \\
\text { day }\end{array}$ \\
\hline Sfrs 10 & Splicing factor, arginine/serine-rich 10 & Translation & -0.4 & -1.1 & -0.6 & -0.9 \\
\hline SImo2 & Slowmo homolog 2 (Drosophila) & Unknown & -0.5 & -0.7 & -0.5 & -0.9 \\
\hline Sox3 & SRY-box containing gene 3 & Transcription, central nervous system development & -0.8 & -1.1 & -1.4 & -1.1 \\
\hline Txnrd1 & Thioredoxin reductase 1 & Electron transport, proliferation & -0.5 & -1.3 & -0.5 & -0.8 \\
\hline Ubfd1 & Ubiquitin family domain containing 1 & Protein modification & & -0.9 & -0.3 & -0.4 \\
\hline Ublcp1 & $\begin{array}{l}\text { Ubiquitin-like domain containing CTD } \\
\text { phosphatase } 1\end{array}$ & Protein modification & -0.4 & -0.7 & -0.3 & -0.9 \\
\hline Uqcrq & $\begin{array}{l}\text { Ubiquinol-cytochrome c reductase, } \\
\text { complex III subunit VII }\end{array}$ & Electron transport & & -0.9 & -0.2 & -0.5 \\
\hline
\end{tabular}

Folds are shown in $\log _{2}$ ratio.

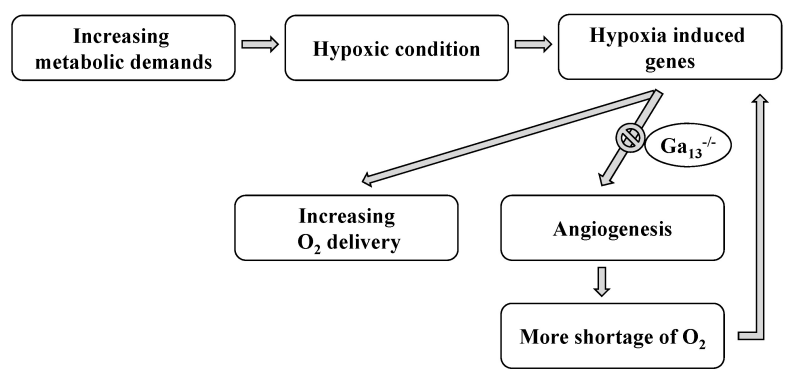

Fig. 5. Mechanisms for the role of $\mathrm{G} \alpha_{13}$ in the angiogenesis and the induction of hypoxic conditions.

(nestin) (Yang et al., 1997), Nr2f1 (nuclear receptor subfamily 2, group F, member 1) (Armentano et al., 2006), Sox3 (Collignon et al., 1996) and Arg1 (arginase, liver) (Yu et al., 2002) are required for the development of mouse central nervous system.

\section{Discussion}

The $\mathrm{G}$ protein $\mathrm{G} \alpha_{13}$ plays a key role in the mouse embryonic development. Several lines of evidence indicate that $G \alpha_{13}$ knockout mice die due to the abnormality of angiogenesis, but the molecular mechanism has not yet been completely elucidated (Offermanns et al., 1997). In order to determine the outcome of $\mathrm{Ga}_{13^{--}}$deletion in mouse embryos, whole gene expression was analyzed using the DNA microarray method. As shown in Fig. $1 \mathrm{~A}$ and Table 1, the genes that participated in the processes of cell differentiation, cell-cell adhesion and angiogenesis, were all continually overexpressed from $9.5 \mathrm{~d}$ to $10.5 \mathrm{~d}$. As shown in Table 3, downregulated genes were related to the cell cycle, DNA replication, protein modification and cell-cell dissociation. This gene level analysis supported the morphological observation of blood vessel sprouting and branching defects due to $G \alpha_{13}$ deficiency. The lack of oxygen as well as the energy and nutrient depletion due to vascular system defects

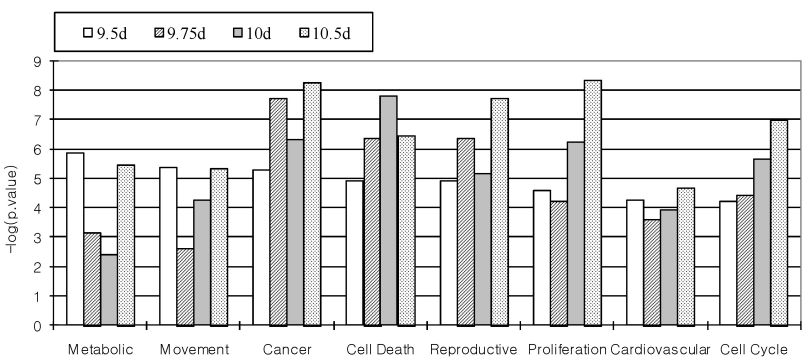

Fig. 6. Significantly affected physiological pathways in $\mathrm{Ga}_{13}{ }^{-1-}$ embryos revealed by Ingenuity Pathway Analysis.

caused the abnormality of organ development in developing mouse embryos. Blood vessels were formed from progenitor cells as $\mathrm{Ga}_{13}{ }^{--}$embryos grew, but division, movement and migration of endothelial cells of blood vessels that are dependent on the $\mathrm{G} \alpha_{13}$ signaling pathway did not occur, thereby inhibiting angiogenesis. Based on our data, a primitive model was constructed as shown in Fig. 5.

The analysis of the whole genome expression data using Ingenuity Pathway Analysis showed statistically significant gene alterations, pertaining to different functional categories and occurring at various time points measured in the knockout mouse embryos (Fig. 6). As shown, the deletion of $G \alpha_{13}$ resulted in not only abnormalities of cardiovascular system but also severe impediments in various other categories including metabolic pathway, movement, cancer, proliferation, cell cycle, etc. The regulation of cancer-related genes is not surprising when we consider the importance of the $\mathrm{G} \alpha_{12} /$ $\mathrm{G} \alpha_{13}$ family members in cancer biology (Spiegelberg and Hamm, 2007).

Taken together, we present the results that were obtained from the whole genome gene expression of $\mathrm{Ga}_{13}{ }^{--}$ mouse embryos compared to wild type littermate embryos, in an attempt to ascertain the roles of $\mathrm{G} \alpha_{13}$ during embryonic development. The results presented here 
throw light on the possible mechanisms of $\mathrm{G} \alpha_{13}$ that are involved in the regulation of angiogenesis and cytoskeletal rearrangements during embryonic development. Moreover, the potential characteristics of $G \alpha_{13}$ and $G \alpha_{12}$ in causing neoplasia (Voyno-Yasenetskaya et al., 1994) as well as their roles in metastasis (Spiegelberg and Hamm, 2007) cannot be ignored, and our study further provides clues to understanding the roles of these enigmatic proteins in cancer angiogenesis.

\section{Acknowledgements}

This work was supported by the Basic Science Research Program through the NRF of Korea funded by the MEST (2010-0015356). This work was also partly supported by the grant from Korea Food \& Drug Administration (10182KFDA992) and the Priority Research Centers Program (NRF 2011-0022978).

\section{References}

Abramovitch, R., Tavor, E., Jacob-Hirsch, J., Zeira, E., Amariglio, N., Pappo, O., Rechavi, G., Galun, E., and Honigman, A. (2004). A pivotal role of cyclic AMP-responsive element binding protein in tumor progression. Cancer Res. 64, 1338-1346.

Arato-Ohshima, T. and Sawa, H. (1999). Over-expression of cyclin D1 induces glioma invasion by increasing matrix metalloproteinase activity and cell motility. Int. J. Cancer 83, 387-392.

Armentano, M., Filosa, A., Andolfi, G., and Studer, M. (2006). COUP-TFI is required for the formation of commissural projections in the forebrain by regulating axonal growth. Development 133, 4151-4162.

Arnaoutov, A. and Dasso, M. (2003). The Ran GTPase regulates kinetochore function. Dev. Cell. 5, 99-111.

Berestetskaya, Y.V., Faure, M.P., Ichijo, $H_{\text {., }}$ and VoynoYasenetskaya, T.A. (1998). Regulation of apoptosis by alpha-subunits of $\mathrm{G} 12$ and $\mathrm{G} 13$ proteins via apoptosis signal-regulating kinase-1. J. Biol. Chem. 273, 27816-27823.

Bosco, M.C., Puppo, M., Santangelo, C., Anfosso, L., Pfeffer, U., Fardin, P., Battaglia, F., and Varesio, L. (2006). Hypoxia modifies the transcriptome of primary human monocytes: modulation of novel immune-related genes and identification of CC-chemokine ligand 20 as a new hypoxia-inducible gene. J. Immunol. 177, 1941-1955.

Buhl, A.M., Johnson, N.L., Dhanasekaran, N., and Johnson, G.L. (1995). G alpha 12 and $G$ alpha 13 stimulate Rho-dependent stress fiber formation and focal adhesion assembly. J. Biol. Chem. 270, 24631-24634.

Chauvet, C., Bois-Joyeux, B., Berra, E., Pouyssegur, J., and Danan, J.L. (2004). The gene encoding human retinoic acid-receptor-related orphan receptor alpha is a target for hypoxia-inducible factor 1. Biochem. J. 384, 7985.

Chen, B., Nelson, D.M., and Sadovsky, Y. (2006). N-myc down-regulated gene 1 modulates the response of term human trophoblasts to hypoxic injury. J. Biol. Chem. 281, 2764-2772.

Collignon, J., Sockanathan, S., Hacker, A., Cohen-Tannoudji, M., Norris, D., Rastan, S., Stevanovic, M., Goodfellow, P.N., and Lovell-Badge, R. (1996). A comparison of the properties of Sox-3 with Sry and two related genes, Sox-1 and Sox-2. Development 122, 509-520.

Cormier-Regard, S., Nguyen, S.V., and Claycomb, W.C. (1998). Adrenomedullin gene expression is developmentally regulated and induced by hypoxia in rat ventricular cardiac myocytes. J. Biol. Chem. 273, 1778717792.

Demartino, G.N. and Gillette, T.G. (2007). Proteasomes: machines for all reasons. Cell 129, 659-662.

Dhanasekaran, D.N. (2006). Transducing the signals: a G protein takes a new identity. SCi. STKE 2006, pe31.

Dhanasekaran, N., Prasad, M.V., Wadsworth, S.J., Dermott, J.M., and van Rossum, G. (1994). Protein kinase C-dependent and -independent activation of $\mathrm{Na}+/ \mathrm{H}+$ exchanger by $G$ alpha 12 class of $G$ proteins. J. Biol. Chem. 269, 11802-11806.

Dutt, P., Nguyen, N., and Toksoz, D. (2004). Role of Lbc RhoGEF in Galpha12/13-induced signals to Rho GTPase. Cell. Signal. 16, 201-209.

Filipek, A. (2006). S100A6 and CacyBP/SIP - two proteins discovered in ehrlich ascites tumor cells that are potentially involved in the degradation of beta-catenin. Chemotherapy 52, 32-34.

Fukuhara, S., Murga, C., Zohar, M., Igishi, T., and Gutkind, J.S. (1999). A novel PDZ domain containing guanine nucleotide exchange factor links heterotrimeric $G$ proteins to Rho. J. Biol. Chem. 274, 5868-5879.

Giatromanolaki, A., Koukourakis, M.I., Gatter, K.C., Harris, A.L., and Sivridis, E. (2007). BNIP3 expression in endometrial cancer relates to active hypoxia inducible factor 1a pathway and prognosis. J. Clin. Pathol. 61, 217-220.

Gohla, A., Harhammer, R., and Schultz, G. (1998). The G-protein G13 but not G12 mediates signaling from lysophosphatidic acid receptor via epidermal growth factor receptor to Rho. J. Biol. Chem. 273, 4653-4659.

Gohla, A., Offermanns, S., Wilkie, T.M., and Schultz, G. (1999). Differential involvement of Galpha12 and Galpha13 in receptor-mediated stress fiber formation. J. Biol. Chem. 274, 17901-17907.

Granata, R., Trovato, L., Lupia, E., Sala, G., Settanni, F., Camussi, G., Ghidoni, R., and Ghigo, E. (2007). Insulinlike growth factor binding protein-3 induces angiogenesis through IGF-I- and SphK1-dependent mechanisms. J. Thromb. Haemost. 5, 835-845.

Hart, M.J., Jiang, X., Kozasa, T., Roscoe, W., Singer, W.D., Gilman, A.G., Sternweis, P.C., and Bollag, G. (1998). Direct stimulation of the guanine nucleotide exchange activity of p115 RhoGEF by Galpha13. Science 280, 21122114.

Hoang, V.M., Foulk, R., Clauser, K., Burlingame, A., Gibson, B.W., and Fisher, S.J. (2001). Functional proteomics: examining the effects of hypoxia on the cytotrophoblast protein repertoire. Biochemistry 40, 4077-4086.

Huang, J.S., Dong, L., Kozasa, T., and Le Breton, G.C. 
(2007). Signaling through G(alpha) 13 switch region I is essential for protease-activated receptor 1-mediated human platelet shape change, aggregation, and secretion. J. Biol. Chem, 282, 10210-10222.

Ito, D., Walker, J.R., Thompson, C.S., Moroz, I., Lin, W., Veselits, M.L., Hakim, A.M., Fienberg, A.A., and Thinakaran, G. (2004). Characterization of stanniocalcin 2, a novel target of the mammalian unfolded protein response with cytoprotective properties. Mol. Cell. Biol. 24, 9456-9469

Jho, E.H. and Malbon, C.C. (1997). Galpha12 and Galpha13 mediate differentiation of P19 mouse embryonal carcinoma cells in response to retinoic acid. J. Biol. Chem. 272, 24461-24467.

Kim, M.S., Lee, S.M., Kim, W.D., Ki, S.H., Moon, A., Lee, C.H., and Kim, S.G. (2007). G alpha $12 / 13$ basally regulates p53 through Mdm4 expression. Mol. Cancer Res. 5, 473-484.

Kitamura, K., Singer, W.D., Star, R.A., Muallem, S., and Miller, R.T. (1996). Induction of inducible nitric-oxide synthase by the heterotrimeric $\mathrm{G}$ protein Galpha13. J. Biol. Chem. 271, 7412-7415.

Koike, T., Kimura, N., Miyazaki, K., Yabuta, T., Kumamoto, K., Takenoshita, S., Chen, J., Kobayashi, M., Hosokawa, M., Taniguchi, A., Kojima, T., Ishida, N., Kawakita, M., Yamamoto, H., Takematsu, H., Suzuki, A., Kozutsumi, Y., and Kannagi, R. (2004). Hypoxia induces adhesion molecules on cancer cells: A missing link between Warburg effect and induction of selectin-ligand carbohydrates. Proc. Natl. Acad. Sci. U.S.A. 101, 8132-8137.

Kozasa, T., Jiang, X., Hart, M.J., Sternweis, P.M., Singer, W.D., Gilman, A.G., Bollag, G., and Sternweis, P.C. (1998). p115 RhoGEF, a GTPase activating protein for Galpha12 and Galpha13. Science 280, 2109-2111.

Ling, Q., Jacovina, A.T., Deora, A., Febbraio, M., Simantov, R., Silverstein, R.L., Hempstead, B., Mark, W.H., and Hajjar, K.A. (2004). Annexin II regulates fibrin homeostasis and neoangiogenesis in vivo. J. Clin. Invest. 113, 38-48.

Manes, T., Zheng, D.Q., Tognin, S., Woodard, A.S., Marchisio, P.C., and Languino, L.R. (2003). Alpha(v)beta3 integrin expression up-regulates cdc2, which modulates cell migration. J. Cell Biol. 161, 817-826.

Manjunath, S., Lee, C.H., VanWinkle, P., and Bailey-Serres, J. (1998). Molecular and biochemical characterization of cytosolic phosphoglucomutase in maize. Expression during development and in response to oxygen deprivation. Plant Physiol. 117, 997-1006.

Martin-Rendon, E., Hale, S.J., Ryan, D., Baban, D., Forde, S.P., Roubelakis, M., Sweeney, D., Moukayed, M., Harris, A.L., Davies, K., and Watt, S.M. (2007). Transcriptional profiling of human cord blood CD133+ and cultured bone marrow mesenchymal stem cells in response to hypoxia. Stem Cells 25, 1003-1012.

Maruyama, K., Mori, Y., Murasawa, S., Masaki, H., Takahashi, N., Tsutusmi, Y., Moriguchi, Y., Shibazaki, Y., Tanaka, Y., Shibuya, M., Inada, M., Matsubara, H., and Iwasaka, T. (1999). Interleukin-1 beta upregulates cardiac expression of vascular endothelial growth factor and its receptor $\mathrm{KDR} / \mathrm{flk}-1$ via activation of protein tyrosine kinases. J. Mol. Cell, Cardiol. 31, 607-617.

Nabors, L.B., Suswam, E., Huang, Y., Yang, X., Johnson, M.J., and King, P.H. (2003). Tumor necrosis factor alpha induces angiogenic factor up-regulation in malignant glioma cells: a role for RNA stabilization and HuR. Cancer Res. 63, 4181-4187.

Offermanns, S., Mancino, V., Revel, J.P., and Simon, M.I. (1997). Vascular system defects and impaired cell chemokinesis as a result of Galpha13 deficiency. Science 275, 533-536.

Olbryt, M., Jarzab, M., Jazowiecka-Rakus, J., Simek, K., Szala, S., and Sochanik, A. (2006). Gene expression profile of B $16(\mathrm{~F} 10)$ murine melanoma cells exposed to hypoxic conditions in vitro. Gene Expr. 13, 191-203.

Oldham, W.M. and Hamm, H.E. (2008). Heterotrimeric G protein activation by G-protein-coupled receptors. Nat. Rev. Mol. Cell Biol. 9, 60-71.

Pandya, N.M., Dhalla, N.S., and Santani, D.D. (2006). Angiogenesis--a new target for future therapy. Vascul. Pharmacol. 44, 265-274.

Plonk, S.G., Park, S.K., and Exton, J.H. (1998). The alpha-subunit of the heterotrimeric $G$ protein $G 13$ activates a phospholipase $D$ isozyme by a pathway requiring Rho family GTPases. J. Biol. Chem. 273, 4823-4826.

Potente, M., Urbich, C., Sasaki, K., Hofmann, W.K., Heeschen, C., Aicher, A., Kollipara, R., DePinho, R.A., Zeiher, A.M., and Dimmeler, S. (2005). Involvement of Foxo transcription factors in angiogenesis and postnatal neovascularization. J. Clin. Invest. 115, 2382-2392.

Radhika, V., Onesime, D., Ha, J.H., and Dhanasekaran, N. (2004). Galpha13 stimulates cell migration through cortactin-interacting protein Hax-1. J. Biol. Chem. 279, 49406-49413.

Ramírez-Solis, R., Davis, A.C., and Bradley, A. (1993). Gene targeting in embryonic stem cells. Meth. Enzymol. 225, 855-878.

Ribatti, D., Nico, B., Spinazzi, R., Vacca, A., and Nussdorfer, G.G. (2005). The role of adrenomedullin in angiogenesis. Peptides 26, 1670-1675.

Riobo, N.A. and Manning, D.R. (2005). Receptors coupled to heterotrimeric $\mathrm{G}$ proteins of the $\mathrm{G} 12$ family. Trends Pharmacol. Sci. 26, 146-154.

Ruppel, K.M., Willison, D., Kataoka, H., Wang, A., Zheng, Y.W., Cornelissen, I., Yin, L., Xu, S.M., and Coughlin, S.R. (2005). Essential role for Galpha13 in endothelial cells during embryonic development. Proc. Natl. Acad. Sci. U.S.A. 102, 8281-8286.

Schwarzer, R., Tondera, D., Arnold, W., Giese, K., Klippel, A., and Kaufmann, J. (2005). REDD1 integrates hypoxia-mediated survival signaling downstream of phosphatidylinositol 3-kinase. Oncogene 24, 1138-1149.

Seghezzi, G., Patel, S., Ren, C.J., Gualandris, A., Pintucci, G., Robbins, E.S., Shapiro, R.L., Galloway, A.C., Rifkin, D.B., and Mignatti, P. (1998). Fibroblast growth factor-2 (FGF-2) induces vascular endothelial growth factor (VEGF) expression in the endothelial cells of forming capillaries: an autocrine mechanism contributing to angiogenesis. J. Cell Biol. 141, 1659-1673. 
172 Genomics \& Informatics Vol. 9(4) 161-172, December 2011

Shan, D., Chen, L., Wang, D., Tan, Y.C., Gu, J.L., and Huang, X.Y. (2006). The G protein $G$ alpha(13) is required for growth factor-induced cell migration. Dev. Cell 10, 707-718.

Shweiki, D., Itin, A., Soffer, D., and Keshet, E. (1992). Vascular endothelial growth factor induced by hypoxia may mediate hypoxia-initiated angiogenesis. Nature 359, 843845.

Simon, M.I., Strathmann, M.P., and Gautam, N. (1991). Diversity of $\mathrm{G}$ proteins in signal transduction, Science 252, 802-808.

Spiegelberg, B.D. and Hamm, H.E. (2007). Roles of G-protein-coupled receptor signaling in cancer biology and gene transcription. Curr. Opin. Genet. Dev. 17, 40-44.

Suzuki, N., Nakamura, S., Mano, H., and Kozasa, T. (2003). Galpha 12 activates Rho GTPase through tyrosine- phosphorylated leukemia-associated RhoGEF. Proc. Natl. Acad. Sci. U.S.A. 100, 733-738.

Tai, Y.T., Podar, K., Gupta, D., Lin, B., Young, G., Akiyama, $M$, and Anderson, K.C. (2002). CD40 activation induces p53-dependent vascular endothelial growth factor secretion in human multiple myeloma cells. Blood 99, 14191427.

Tazuke, S.I., Mazure, N.M., Sugawara, J., Carland, G., Faessen, G.H., Suen, L.F., Irwin, J.C., Powell, D.R., Giaccia, A.J., and Giudice, L.C. (1998). Hypoxia stimulates insulin-like growth factor binding protein 1 (IGFBP-1) gene expression in HepG2 cells: a possible model for IGFBP-1 expression in fetal hypoxia. Proc. Natl. Acad. Sci. U.S.A. 95, 10188-10193.
Tsopanoglou, N.E. and Maragoudakis, M.E. (1999). On the mechanism of thrombin-induced angiogenesis. Potentiation of vascular endothelial growth factor activity on endothelial cells by up-regulation of its receptors. J. Biol. Chem. 274, 23969-23976.

Voyno-Yasenetskaya, T., Conklin, B.R., Gilbert, R.L., Hooley, R., Bourne, H.R., and Barber, D.L. (1994). G alpha 13 stimulates $\mathrm{Na}-\mathrm{H}$ exchange. J. Biol. Chem. 269, 4721-4724.

Voyno-Yasenetskaya, T.A., Pace, A.M., and Bourne, H.R. (1994). Mutant alpha subunits of $\mathrm{G} 12$ and $\mathrm{G} 13$ proteins induce neoplastic transformation of Rat-1 fibroblasts. Oncogene 9, 2559-2565.

Wang, L., Kwak, J.H., Kim, S.I., He, Y., and Choi, M.E. (2004). Transforming growth factor-beta1 stimulates vascular endothelial growth factor 164 via mitogen-activated protein kinase kinase 3-p38alpha and p38delta mitogen-activated protein kinase-dependent pathway in murine mesangial cells. J. Biol. Chem. 279, 33213-33219.

Wang, V., Davis, D.A., Haque, M., Huang, L.E., and Yarchoan, R. (2005). Differential gene up-regulation by hypoxia-inducible factor-1alpha and hypoxia-inducible factor-2alpha in HEK293T cells. Cancer Res, 65, 32993306.

Yang, J., Bian, W. and Jing, N.H. (1997). Nestin mRNA expression during the development of mouse central nervous system. Sheng Li Xue Bao 49, 657-665.

Yu, H., lyer, R.K., Yoo, P.K., Kern, R.M., Grody, W.W., and Cederbaum, S.D. (2002). Arginase expression in mouse embryonic development. Mech. Dev. 115, 151-155. 